\title{
EDUCATION IN TIMES NET GENERATION: HOW DIGITAL IMMIGRANTS CAN TEACH DIGITAL NATIVES?
}

\author{
H. V. CHAVES ${ }^{*}$, O. N. MAIA FILHO and A. S. E. MELO \\ Universidade de Fortaleza \\ hamilton@unifor.br*
}

Article submitted in October/2015 and accepted in March/2016

DOI: 10.15628/holos.2016.3611

\section{ABSTRACT}

Members of the knowledge society, of the network society or of the informatics society are some names that seem to define the current generation. Net generation is a generic nomenclature which covers all the previous terms. Digital immigrants are the subjects whom were born before the advent of digital technologies and who joined to them. Digital natives are the subjects whom were born in the current generation and that would have special qualities, especially regarding the learning process. Considering all this context, a question arises: how the digital immigrants teach the digital natives? This
\end{abstract}

item justifies itself because there is a meeting of generations, in theory, significantly differentiated. Due to this, it would be necessary to identify the appropriate educational forms according to the presented situation. Our teaching experience convinces us that, yes, we should valorize the information's technologies and communication, understanding that these are means, not ends. It is important to highlight that any tool causes advances and regressions, a fact that serves to guide our teaching practice.

KEYWORDS: net generation, digital immigrants, digital natives, teaching and learning.

\section{EDUCAÇÃO EM TEMPOS NET GENERATION: COMO OS DIGITAL IMMIGRANTS PODEM ENSINAR OS DIGITAL NATIVES?}

\section{RESUMO}

Membros da sociedade do conhecimento, da sociedade em rede ou da sociedade informática são alguns nomes que parecem definir a atual geração. Net generation é uma nomenclatura genérica que aborda todos os qualificadores anteriores. Digital immigrants são os sujeitos natos antes do advento das tecnologias digitais e que se incorporaram a elas. Digital natives são os sujeitos nascidos na atual geração e que seriam possuidores de qualidades especiais, sobretudo no que diz respeito à aprendizagem. Considerando todo este contexto uma questão se põe: como os digital immigrants ensinam aos digital natives? Tal quesito se justifica porque há o encontro de gerações, em tese, significativamente diferenciadas, sendo, assim, far-se-ia necessário identificar formas educativas apropriadas de acordo com a situação que se apresenta. Nossa experiência docente nos convence de que devemos, sim, valorizar as tecnologias de informação e comunicação entendendo que estas são meios e não fins. É importante destacar que qualquer ferramenta provoca avanços e retrocessos, fato que nos serve de baliza para nossa prática docente.

PALAVRAS-CHAVE: net generation, digital immigrants, digital natives, ensino e aprendizagem. 


\section{INTRODUCTION}

It was in the beginning of the 1980s, that the Polish Adam Schaff (1990) launched his markable work Wohin führt der Weg. His futurist text contained a sociological analysis of the impacts about what is called the second industrial revolution. The text is avant-garde and concerns to the advances of technology supported by the microelectronics and embedded in industrial production and provision of services. If the first industrial revolution was marked by the gradual replacement of the human force by steam engines and, later, by electrical machines; The second stage is characterized by refining the mechanisms in terms of discrete components, made possible by the encapsulation of electronic circuits in silicon tablets. This represented, at that time, that machine models that existed so far as projects that could be implemented and put to the service of the production of goods and circularity of information.

Only five years later, it was the turn of Pierre Lévy (1993) approach, in his work Les technologies de l'intelligence, the effects of this second industrial revolution in the human intelligence. He highlighted three major times of the human spirit: the primary orality (the secondary orality refers to the transformation of orality as a result of using the writing), the writing and informatics. What is put in question in each of these moments is the capacity of representation, manipulation of reality in terms of past redemption, the explicitness of present experience and future projection of human achievements. If we consider, in a summarily simplistic way, that to represent concerns to the use of symbolic and/or instrumental elements to express human thinking; primary orality, writing and informatics, they have the same characteristics and differentiated qualitative. What unifies is the interposition, between the human thought and the phenomenological world, of elements of mediation (or instrumentals): the spoken word, the written word and the word in terms of binary codes.

If we take on the contribution of Pozo (2002), we could interpolate between the writing and the informatics the system invented by Gutenberg, in the XIV century. This made possible, in his view, a better conservation of the information recorded in the alphanumeric systems, as well as increased the advertising and secular system of information, the basis of modern scientific and a new culture of learning. Flusser (1985), in turn, suggests another intermediary: the photographic camera as an embryo of the informational devices. In the society of the devices that we live nowadays, says Flusser, the subject is no longer in the opposite side of the machine, but inside of it (and the camera it is in the subject), so he program the camera and it is programmed by it.

It is clear that the way the word appears in each of these times also keeps particular qualities. The spoken word requires more of the biological apparatus in terms of memory, something that Vygotsky (2000) would appoint as lower psychological functions. The written word allows postpone immediately to work with applications that wouldn't depend of the biological apparatus as the only resource. According to Flusser (2010), the writing produces its own history, freeing the subject of graphic culture and circular oral speech, expanding the possibilities of broadening memory and automatic registration, of future, dialectic and critical of the symbolic. Finally, the word in terms of binary codes makes it possible, abysmally, manipulate huge amounts of representations at a speed which, apparently, speaking and writing did not allow.

Quantity and speed of binary computer words being processed and shared made happen a quality that Castells (2006) called network society. It is an instant exchange of words between users with commercial, industrial, educational, or even recreation purposes. The most famous sharing network is, undoubtedly, the internet. It was in the 1990s that this global network wasn't any 
longer exclusive for scientific and military purposes and began to be exploited for other purposes. It is in this context of commercial, industrial, educational and recreation that the internet arises, according to Oblinger and Oblinger (2005), a generation known as net generation. Fomented since the early 1980s and cream in the next decade, this generation, also known as the millennials, is characterized by the hopeful determination, public activism and taste for technological innovations, especially the highly graphic, at the same time that doesn't appeals for slow stuff and negativity.

It was from this temporal demarcation that Prensky (2001) characterized what would be digital immigrants and digital natives. The digital immigrants would be those individuals who, although didn't born in the net generation, now have access to the words of binary codes from the Information and Communication Technologies (ICT). In turn, the digital natives would be the very subjects of the net generation. Also according to the author, the subjects digital natives developed, because of the whole context in which they are inserted, new and sophisticated cognitive abilities and radically differentiated styles of learning.

Considering all this context a question arises: how the digital immigrants teach the digital natives? This question is justified because there is a meeting of generations, in theory, significantly different, so it is necessary to identify appropriate educational forms according to the situation at hand: a new culture of learning (POZO, 2002).

\section{METHOD}

This is a qualitative and exploratory study, in which we seek to confront the recent research of specialized literature with our view as professors of the university, specifically with students linked to graduate and postgraduate programs. Therefore, we conducted a narrative review of the literature (CORDEIRO; OLIVEIRA; REINTERÍA; GUIMARÃES, 2007) and tailor with our teaching practice. Is it our posture and teaching practice suitable with the current context of the net generation? In other words, how we, as digital immigrants, deal with the digital natives in the matter to teaching and learning? These are some questions we want to answer in the coming lines.

\section{RESULTS AND DISCUSSION}

The circularity of information, above all facilitated by the manipulation of binary codes words, seems to be an inexorable reality. When applied to education, equally, tells us that we are traveling on an one-way path which would require us, in terms from Piaget, a constant major balancing or accommodation. This process indicates that the intelligence balance status is constantly threatened by these numerous innovations in technology, which would require the subject to adapt and, therefore, promote cognitive advances.

Based on Vygotsky (2000), Wertsch (1998) understands that when we are introduced to a new tool, our senses adapt themselves as affordance (according Günther (2003). Affordance is a neologism that still does not find exact definition in the English language, but that can be understood as the environmental characteristics that require cognitive adaptation and, in certain way, a different course of action of the subject) and restrictions concerning to the adaptation of the environment are gradually dissipated, appearing, therefore, new ways of dealing with goals and actions as they presents themselves in the context. If we consider the demarcations established by Prensky (2001), to the digital immigrants the questionings about the adaptation of 
the subject would be bigger in economic terms (cognitive energy) if compared to the digital natives (Anderson, 1990).

Generally, the digital natives would be possessors of characteristics that would put them in confrontation with the digital immigrants. Homo zappiens is the term Veen and Vrakking (2006) give to the contemporary status of development of the human intelligence. In general, Zap refers to the search for key elements of information that express this significantly. The authors say that the cognition mode of operation in the current generation gives the iconicity a leading role, due to learning being based on the competence of handling this type of sign. However, the traffic between the iconic information is given non-linearly, by links, which is similar to the hypertexts structure.

This causes capillarity in the search for information and would requested of the subjects that they worked in a multitask mode, while easily converge for collaborative information networks. For Flusser (2010), digital writing (overwriting) is more visual than musical; more math, denotative and objectively, than writing lyrical, connotative and subjective of the ancient minted texts on hard surfaces. Therefore, the digital writing would be dominated by the iconicity of technical images (devices) and not the dialectic of symbolic language.

Almost immediately and reactively, the digital immigrants would not see all this situation willingly. For them, the students would need to exceed the level of iconicity, once they understand that to endorse this type of sign would put the digital natives in superficiality. They also agree that the operation multitasking would not contribute in the regulation of human attention, in a way that the subjects would easily disperse themselves. Finally, such collaborative information networks do not always exceed the level of mere textual copy.

From these different postures what can we really conclude of this exchange of ideas? It seems, to us, that this matter needs to be further analyzed starting from the empirical data that would put them to meet our reflections, regarding to our teaching practices.

The first point to evaluate concerns the arguments used on the technological skills and educational preferences of the digital natives. Waycott, Bennett, Kennedy Dalgarno and Gray (2010) consider that such arguments are ad hominem ${ }^{1}$. Once they have been based on "guesses and anecdotal reports" (p. 1202). To escape such assumptions, the authors conducted a thorough research with qualitative approach in which the subjects were students and teachers who belonged to three Australian universities. The central question was: how and why they use technologies? It was also investigated their opinions on them. It has been made 12 individuals interviews, from a semi-structured script and 6 focal groups, a study design involving 46 subjects. The results of the study indicated that there is no substantial difference between the younger students and fans of technology (digital natives) and their teachers (digital immigrants) allegedly caused by exposure to technology throughout their lives.

The research by Margaryan, Littlejohn and Vojt (2011), meanwhile, was made from a frame that collected quantitative and qualitative data. The goal was to seek which technological tools are used and how often they are used in formal and informal learning and recreation. It was also object of investigation the perceptions of the educational value of technology tools as well as the motivations for the use of certain types of technology. The study included 160 students of engineering courses and social work of two UK universities. The average age of the subjects was 23 years $(S D=6.32)$, aged between $19-50$ years, and being the engineering students significantly

1 Arguments that lend to confuse the opponent. 
younger than the social service (average $=21, S D=2.4$ versus average $=33 \mathrm{SD}=8.7$ ). Some of the quantitative data are shown in the chart 1.

Chart 1 - Digital devices by course and age

\begin{tabular}{|l|c|c|c|c|}
\hline \multicolumn{1}{|c|}{ Hardware Device } & Engineering & Social Work & Digital natives & Digital immigrants \\
\hline Mobile phone & $130(100 \%)$ & $29(96.7 \%)$ & $134(100 \%)$ & $22(95,6 \%)$ \\
Personal computer & $104(80 \%)$ & $23(76,7 \%)$ & $104(77,65 \%)$ & $20(86,9 \%)$ \\
Laptop computer & $89(68,5 \%)$ & $17(56,7 \%)$ & $89(66,4 \%)$ & $14(60,9 \%)$ \\
Digital camera & $75(57,7 \%)$ & $17(56,7 \%)$ & $75(56,0 \%)$ & $14(60,9 \%)$ \\
Other $^{*}$ & $9(6,9 \%)$ & $1(3,3 \%)$ & $9(6,7 \%)$ & $2(8,7 \%)$ \\
\hline
\end{tabular}

Adapted from Margaryan, Littlejohn e Vojt (2011)

* video camera, pen drive, GPS etc.

From the analysis of quantitative and qualitative data the authors maintain that there is no evidence that the current generation of students adopt radically learning styles exhibiting new forms of literacy from the use of sophisticated technologies. In fact, the attitudes of students in regard to learning, seems to be influenced more by the teaching methods used by teachers. These results are in line with the conclusion Kennedy, Judd, Churchward, Gray and Krause (2008) for which the fact that the subject belongs to the net generation would not be synonymous of being able to use all the digital technologies strategically to improve learning. It is a fact that even if it was an argue here that we are at a moment of transition between two generations (digital natives and digital immigrants), the data seems to generate some perplexity: the digital natives remains sensitized by the "traditional" strategies of the digital immigrants; The latter appears to incorporate the new universe surprisingly quickly, for realizing the new technologies appears more like a means than an end.

In the case of social networks Kirschner and Karpinski (2010) conducted a study that linked the use of Facebook (FB) and the academic performance. The data were collected from a sample of 102 graduate students and 117 postgraduate students from a US university. The average age of the students was approximately $22.06(S D=3.72)$ and $30.29(S D=7.03)$ for each respective group. The interview script consisted of five sections of closed type yes/no answers, Likert scale, and open response items. The dependent variables were the Grade Point Average (GPA), a rate that is similar to the global average or academic performance, and hours of study per week. The variance analysis of data indicated that the groups of users and non FB users are significantly different. Comparatively, FB users have lower GPA and study fewer hours per week compared to non-users.

These studies suggest that the relationship between teaching and learning in the net generation is not something easy to solve. Is not dichotomies that will establish the educational criteria of digital natives by the digital immigrants. At least this has been one of the conclusions of Jones, Ramanau, Cross and Healing (2010). They conducted a survey of students from five English universities that sought to identify if a different generation was entering the higher education institutions in England. The results pointed to a picture indeed complex, which means, although there are significant variations related to age between digital natives and digital immigrants, we cannot describe those born after 1983 as belonging to a single generation. The study at hand concluded that the last generation is not homogeneous with respect to the use and exploitation of new technologies and that there are significant variations within this group.

Salajan, Schönwetter, Cleghorn (2010) reached similar conclusions. When investigating a group of students and dental college professors, in the University of Toronto, towards to intergenerational segmentation (natives digital and digital immigrants) and the use of technology, realized that the differences between the groups was minimal, with no universal applicability of 
terms. In fact, the study concluded that the groups formed a complex phenomenon that, often, cannot be absorbed by extreme terms.

Briefly, all these studies presented above compose a reference chart that can hardly be summarized by binary taxonomies. This evidence points to one question: the digital natives spontaneously would appropriate of technological resources? It is true that this issue may cause us, in the words of Bennett, Maton and Kervin (2008), certain "moral panic" for us, digital immigrants, not being in possession of such spontaneity. Critically analyzing the situation at hand, we can better conduct the debate in such way that the demarcation between digital natives and digital immigrants would have a more chronological and historical value than educational.

This argument would be sustained when we infer from the work of Prensky (2001), Oblinger and Oblinger (2005) and Veen and Vrakking (2006) certain attempts to design this so-called spontaneity as a natural phenomenon, which would be a serious mistake, in our understanding. In an endeavor to solve this paradox, we can resume the debate nature versus nurture, nativism versus environmentalism, but it seems that, once again, this kind of ambivalent discussion does little to clarify the issue.

To build some ways in this trail of complexity, we make use of some arguments developed by Koyrè (1991), in the philosophy, and Vygotsky (2000), in the context of psychology. For the first thinker, the itinerary in the search for truth is not a direct route; in practice, experiments deflections that, many times, seems to be pushing away from our goals. When we apply this idea to the field of technology we can elucidate confrontations, especially when we turn to the fact that in the field of digital technology reigns certain epistemology of progressivist linearity. This line of thought says that the recent knowledge is always better prepared than its predecessor. In technological terms, the Web 2.0 is much more effective and evolved than its predecessor. No need to go far to understand the fury that this causes in some and the "moral panic" in others.

Since the revolution of the cognitive sciences that started in the 1950s, those who praise themselves with their findings and contributions, particularly the binary logic, have lived moments of excitement and anxiety (DUPAY, 1996). Apparently, digital technologies make possible the real expansion of human thought, since their tools would broaden the line of human's reason horizon. The study Kirschner and Karpinski (2010) shows that this is not so and it is at this point that we can approach what appears is happening on the net generation by psychological perspective.

Perhaps one of the greatest contributions of Vygotsky (2000, p. 29) to human thinking has been the concept of higher psychological functions. It is, in the author's words, those psychic functions extended by instrumental development and appropriation of symbolic complexity. As the author says:

[...] first of all, about the processes of domain of the external means concerning to cultural development and thinking: language, writing, calculation, design; and, second, the development process of the special higher mental functions, not limited or determined with accuracy, which in traditional psychology are called voluntary attention, logical memory, concept formation, etc.

From Vygotsky's perspective, Wertsch (1985) states that, in the case of higher psychological functions expressed by supported instrumental development in the symbolic, we can experience two effects: advances and setbacks, which goes against the assumption of the linearity epistemology. Based on the dialectical conception of development of human thought, this idea of profit and loss occurs because, while the instruments allow the human accomplishments that your 
biology would limit (advances), they would also prevent him from expanding, within limits of the symbolic, his cognitive abilities (setbacks). This perspective guides our teaching practices in the past years, as to there is more caution and less confusion in relation to digital technologies. At this point we can return to our initial question, which is: how the digital immigrants teach digital natives, and share our experiences.

These studies have previously associated our experiences, leading us to believe that there are no significant special differences between the generations in question in regard to teaching and learning. In fact, the differences must be analyzed within microcontexts, as we warned earlier (KEYS; MAIA SON; MELO, 2015). The demarcation spread by Prensky (2001) has much more a chronological value and sets the definition of the appearance of technologies than have psychological and pedagogical implications in the field of formal learning in higher education, because the effects of a new culture takes time to materialize, even if the mark of this current culture is exactly the time acceleration.

It seems that the challenge of the digital immigrants is not to become obsolete. Every day is a huge amount of new artifacts, new research, new methods and theories that are published and we need to take advantage of these resources. But we emphasize that the changes are supported by the strategies generated by digital immigrants, and that these changes are the result of the point of view performed previously.

The information and communication technologies should be used by us, teachers of higher education, in our teaching practices, within limits which we consider acceptable and safe for development assistance to the learning and performance of our students. For us, quantity and speed of information are not essential given that, regardless of generation, because we are not "informivores" The technologies are seen by us as complementary, given its limiting factors. As reminds us Flusser (1985), the information is the basis of the current culture, as the etymology indicates, is about the knowledge "in formation", of data to be formed, worked, seized and incorporated into the subject as meaningful learning (MARTINS; SILVA, 2016; SALES JR.; RAMOS; PINHO; SANTA ROSA, 2106).

Therefore, we use frequently the possible effects of the technologies that we employ in the classroom in order to avoid any distortions concerning the production of knowledge and social relations. This is not an entrenchment or mechanism of resistance to new technologies, but a caution to the binary base, imagery, iconic and objectifying of information culture does not accelerate fundamental losses of other dimensions of our cultural achievements: the symbolic dimension, denotative, subjective, musical and non-programmable keeps us as autonomous subjects, creative and knowledge producers. Also, we should continue to investigate what technology tools are useful for teaching and how often its uses takes place in the context of learning.

Finally, we cannot forget that the mission of the university, especially as production realm of knowledge and culture, is to produce the new, the future, and to this it is important to figure out how to move from the past production and continue to be what we still are not. Our challenge is to become a hypertext university, where each one can capture the benefits and question the directions of technological inventions. 


\section{CONCLUSION}

Instant messages, web 2.0, blog, wiki, social networks, youtube, cloud computing, which will be the next technology? Deep Web? These issues are embedded in a number of other relevant questions to the topic that motivated our discussion. Paradoxically, there was the inexorability of the net generation, that reflects certain ephemerality of the technologies themselves. The challenge is to live with them, so the advances in knowledge are far more significant than the setbacks.

What we tried to walk away is the naturalization of the subject of learning whose belonging to historical moments would be defined by his knowledge construction behavior. Would be the subject only a reflection of his surroundings? Would be the digital natives correspondent to their environments? Certainly seems that these issues points to thesis already so debated and that are proved so fragile, given that lend themselves much more to the reflective and ideological speculation that a careful evaluation of historical moments.

Beyond the understanding that the subject of learning is not naturally and non-historically constituted another approach motivates us in our teaching placement: the market logic of technologies. This seems to be a matter quite more evident when we see that the technologies are created and commercialized in an immeasurable speed. Some tools are stillborn not for their quality itself, but for the fierce competition towards the consumer market that is often based on the mere raising of users where ethics and social life do not make the rules.

It is in this sense that we can question even the concept of the knowledge society and the circularity of information. What level of authorship and autonomy of the subject when delegates almost entirely to digital tools the production of knowledge? The options for research on the internet are scarce, practically only one service on a global network, which is to be found; this is circularity of the information? The history of mankind convinces us that merely reactive acts, such as those ludic, and its conception of utopian socialism, it seems contribute to social development, especially of knowledge, which means being a prisoner of certain technological optimism. What is most interesting in this moment was trying to show how is structured the relationship between technology and teaching.

The educational approach should show committed to the conservation of culture, but also and equally with the advancement of knowledge, the professional training and the social justice. Thus, our teaching placement is towards to appreciate technologies as a mediator tool in conservation and production of knowledge. However, we note that this appreciation is surrounded by care for the subject and its sensibility does not fade out. This happens through the appreciation of personal meetings, face to face, in the emergence of differences and conflicts and overcoming them. It is healthy that the student and the teacher experiment daily the classroom as a space of cultural exchanges, the experience of the learning environment that allows all human sensibility.

\section{REFERENCES}

1. ANDERSON, J. R. Cognitive psychology and implications. 3 ed. NY: W. H. Freeman and Company, 1990.

2. BENNETT, S., MATON, K., KERVIN, L. The 'digital natives' debate: A critical review of the evidence. British Journal of Educational Technology, v.39, n.5, p.775-786, Fev, 2008.

3. CASTELLS, M. Comunicación móvil y sociedad: una perspectiva global. Madrid: Siglo XXI, 2006. 
4. CHAVES, H. V., MAIA FILHO, O. N., MELO, A. S. E. Educação e microrrelações humanas na educação profissional e tecnológica. Revista Brasileira de Ensino de Ciência e Tecnologia, v.8, n.1, p. 56-69, Jan. 2015.

5. CORDEIRO, A. M., OliVEIRA, G. M., RENTERÍA, J. M., GUIMARÃES, C. A. Revisão sistemática: uma revisão narrativa, Revista do Colégio Brasileiro de Cirurgiões, Rio de Janeiro, v.34, n.6, nov. 2007.

6. DUPAY, J. P. Nas origens das ciências cognitivas. São Paulo: UNESP, 1996.

7. FLUSSER, V. Filosofia da caixa preta: ensaios para uma futura filosofia da fotografia. São Paulo: Hucitec, 1985.

8. FLUSSER, V. A escrita: há futuro para a escrita? São Paulo: Annablume, 2010.

9. GÜNTHER, H. Mobilidade e Affordance como cerne dos estudos Pessoa-Ambiente. Estudos de Psicologia, v.8, n.2, p.273-280, mai. 2003.

10. JONES, C., RAMANAU, R., CROSS, S., HEALING, G. Net generation or Digital Natives: Is there a distinct new generation entering university? Computers \& Education, v.54, n.3, p.722-732, Abr. 2010.

11. KIRSCHNER, P. A., KARPINSKI, A. C. Facebook and academic performance. Computers in Human Behavior. v.26, n.6, p.1237-1245, Nov. 2010.

12. KENNEDY, G., JUDD, T., CHURCHWARD, A., GRAY, K., KRAUSE, K.-L. First year students' experiences with technology: are they digital natives? Australasian Journal of Educational Technology, v.24, n.1, p.108-122, Sep. 2008.

13. KOYRÈ, A. Estudos de história do pensamento científico. 2 ed. Rio de Janeiro: Forense Universitária, 1991.

14. LÉVY, P. As tecnologias da inteligência. Rio de Janeiro: Ed. 34, 1993.

15. MARGARYAN, A., LITTLEJOHN, A., VOJT, G. Are digital natives a myth or reality? University students' use of digital technologies. Computers \& Education, v.56, n.2, p.429-440, Feb. 2011.

16. MARTINS, J. L., SILVA, B. Narrativas da dependência nas redes de aprendizagem online: como os professores usam as redes de aprendizagem para promover a autonomia. Holos, [s.I.], v.1, p.16-30, Mar. 2016.

17. OBLINGER, D., OBLINGER, J. Is it age or IT: first steps towards understanding the net generation. In D. OBLINGER, D.; OBLINGER, J. (Eds.). Educating the Net Generation. Boulder, CO: EDUCAUSE, 2005, p.2.1-2.20.

18. PRENSKY, M. Digital natives, digital immigrants: do they really think differently? On the Horizon, v.9, n.6, p.1-6, Dec. 2001.

19. POZO, J. I. Aprendizes e mestres: a nova cultura da aprendizagem. Porto Alegre: Artmed, 2002.

20. SALAJAN, F. D., SCHÖNWETTER, D. J., CLEGHORN, B. M. Student and faculty inter-generational digital divide: Fact or fiction? Computers \& Education, v.55, n.3, p. 1393-1403, Nov. 2010.

21. SALES JR., RAMOS, M. A. S., PINHO, A . L. S., SANTA ROSA, J. G. Pedagogical usability: a theoretical essay for e-learning. Holos, [S.I.], v.1, p. 3-15, Mar. 2016.

22. SCHAFF, A. A sociedade informática: as consequências sociais da segunda revolução industrial. São Paulo: Brasiliense/Unesp, 1990. 
23. VEEN, W., VRAKKING, B. Homo Zappiens: growing up in a digital age. London: Network Continuum Education, 2006.

24. VYGOTSKI, L. S. Obras escogidas, Problemas del desarrollo de la psique. 2 ed. Tomo III. Madrid: Visor, 2000.

25. WAYCOTT, J., BENNETT, S., KENNEDY, G., DALGARNO, B., GRAY, K. Digital divides? Student and staff perceptions of information and communication technologies. Computers \& Education, v.54, n.4, p.1202-1211, Mai. 2010.

26. WERTSCH, J. Vygotsky and social formation mind. Cambridge: Harvard University Press, 1985.

27. WERTSCH, J. Mind as action. NY: Oxford University Press, 1998. 